\title{
Rediscovery of rodents (Genus Nesoryzomys) considered extinct in the Galápagos Islands
}

\author{
Robert C. Dowler, Darin S. Carroll and Cody W. Edwards
}

\begin{abstract}
The history of the endemic rodents of the Galápagos Islands began with the discovery of the first Galápagos rice rat species by Charles Darwin in 1835 and the last species was described as recently as 1980 . Unfortunately, of the seven described species known to occur in the islands during the past 150 years, only two were known to be extant to 1995 . Since then, two expeditions to the Galápagos Islands have been conducted to survey endemic rodent populations. The first confirmed the existence of a small endemic rice rat, Nesoryzomys fernandinae, on Fernandina, known previously only from owl pellet remains found in 1979. In 1997, an expedition to Santiago revealed a population of the larger rice rat $N$. swarthi, a species collected alive only once in 1906 and considered extinct in all recent literature on the Galápagos Islands. Survey efforts on Santa Cruz resulted only in the collection of introduced
\end{abstract}

rodent species (Rattus rattus, $R$. norvegicus and $M u s$ musculus). The extant species of native rodents in the Galápagos Islands now number four: N. narboroughi and $N$. fernandinae on Fernandina; $N$. swarthi on Santiago; and Oryzomys bauri on Santa Fe. Three species are found on islands where no introduced rodents or cats occur, whereas only one (N. swarthi) co-exists with R. rattus and M. musculus. Nesoryzomys darwini and $N$. indefessus on Santa Cruz and O. galapagoensis on San Cristóbal are still considered extinct. Strategies for conservation should include monitoring islands for introduced rodents and cats, development of emergency plans in the event of introductions, and captive management.

Keywords Conservation, Ecuador, extinction, Galápagos, islands, Nesoryzomys, Oryzomys, Rattus, rodent.

\section{Introduction}

Conservation of the biota of the Galapagos Islands is an increasing concern because of growing human populations and the impact of introduced species. The extirpation of native species of flora and fauna is not uncommon on some islands and extinction of some species has occurred (Steadman et al., 1991). The endemic rodent fauna is one part of the biota that has undergone considerable impact during this century.

The first endemic rodents of the Galápagos archipelago were collected by Charles Darwin on San Cristóbal in 1835 and described in 1839 as Mus galapagoensis by Waterhouse (1839). Since then, six additional species of native rodents have been described from four other islands in the archipelago. All species are now recognized as belonging to one of two genera: Oryzomys and Nesoryzomys (Patton \& Hafner, 1983). Of

Robert C. Dowler (corresponding author) Department of Biology, Angelo State University, San Angelo, TX 76909, USA. Tel: +1 915/942-2189 extension 239; fax: + 1 915/942-2184; e-mail: robert.dowler@angelo.edu

Darin S. Carroll and Cody W. Edwards Department of Biology, Angelo State University, San Angelo, TX 76909, USA. Current address: Department of Biological Sciences, Texas Tech University, Lubbock, TX 79409, USA. the seven species known to occur in the Galápagos since Darwin's first discoveries, as many as five have been considered extinct. In addition to these species, evidence for one or more extinct rodent species on several islands, including a third genus (Megaoryzomys), is available in the form of fossil skeletal material (Steadman, 1981; Steadman \& Ray, 1982; Steadman et al., 1991; Hutterer \& Oromí, 1993). We undertook this research to survey islands where endemic rodent species have been known to occur and to establish the current status of populations of both native and introduced species of rodents.

\section{History of rodent discoveries in the Galápagos Islands}

The species first collected by Darwin from Chatham Island (=San Cristóbal, see Fig. 1) in 1835 was later placed in the rice rat genus Oryzomys by Allen (1892). In that paper, Allen also described a second closely related species, $O$. bauri, from what is now Santa Fe (= Barrington). Later that decade, a large rice rat was discovered on Santa Cruz (= Indefatigable) in 1897 and described as a new species, $O$. indefessus, in 1899 (Thomas, 1899). Soon thereafter, Heller (1904) described the genus Nesoryzomys, based on specimens of a new species from Fernandina (N. narboroughi) and included 
O. indefessus in it. Nesoryzomys narboroughi was also a large rice rat in the same size class as $N$. indefessus but differed in pelage colour. The validity of the genus Nesoryzomys was questioned throughout much of the century, and many researchers considered it a subgenus of Oryzomys (Ellerman, 1941; Corbet \& Hill, 1980). Morphological, chromosomal and electrophoretic studies, however, have revealed Nesoryzomys to be so distinctive relative to other oryzomyine rodents that generic status was warranted (de Beaufort, 1963; Gardner \& Patton, 1976; Patton \& Hafner, 1983). Patton \& Hafner (1983) proposed an origin for Nesoryzomys in the Galápagos at 3-3.5 million years before present, based on electrophoretic analysis.

Nesoryzomys darwini, a species markedly smaller than either of the previously named Nesoryzomys, was first discovered on Santa Cruz in 1929 (Osgood, 1929), becoming the fifth reported native species of the archipelago. In 1938, a sixth Galápagos endemic rodent, N. swarthi, was described as a new species from Santiago, based on five specimens collected in 1906 by the California Academy of Science Expedition (Orr, 1938). The last species of endemic rodent, $N$. fernandinae, was described as recently as 1980 from skeletal remains in owl pellets found on Fernandina (Hutterer \& Hirsch, 1980). This species was markedly smaller than $N$. narboroughi, which also occurs on Fernandina, based on the size of skulls found, and was in the same size class as $N$. darwini.

\section{Taxonomy of the endemic rodent fauna}

The history of taxonomy in this group has seen the naming of a new species for each newly discovered rodent population on a different island. The single comprehensive assessment of taxonomy for Galápagos rodents was conducted by Patton \& Hafner (1983). These authors based their taxonomic conclusions on a variety of data sets, including morphology of skulls, pelage colour, anatomy of male reproductive tracts and stomachs, protein electrophoresis, and chromosome number and morphology. They lamented, however, that their database was 'frustratingly incomplete because of the apparent extinction of four of the species in question'. Their research addressed the taxonomic status of all species except $N$. fernandinae, which was described as a new species (Hutterer \& Hirsch, 1980) after their research was in press.

Based on the available data, Patton \& Hafner (1983) agreed with earlier studies (Heller, 1904; Osgood, 1929; Cabrera, 1961) that suggested that $O$. bauri and $O$. galapagoensis were so similar that they might be considered conspecific. Because $O$. galapagoensis has not been collected since Darwin's visit in 1835, all assessments have been based solely on morphological data. Electrophoretic comparisons of $O$. bauri from Santa Fe with $O$. xantheolus from Peru showed considerable similarities, leading Patton \& Hafner (1983) to propose that the arrival of Oryzomys to the Galápagos Islands may have occurred very recently, as late as a few hundred to a thousand years ago.

Patton \& Hafner (1983) further presented morphological data showing that the large-bodied rice rats, Nesoryzmys indefessus, N. narboroughi and N. swarthi, are very similar in size and that differences among the species are based primarily on colour variation. They

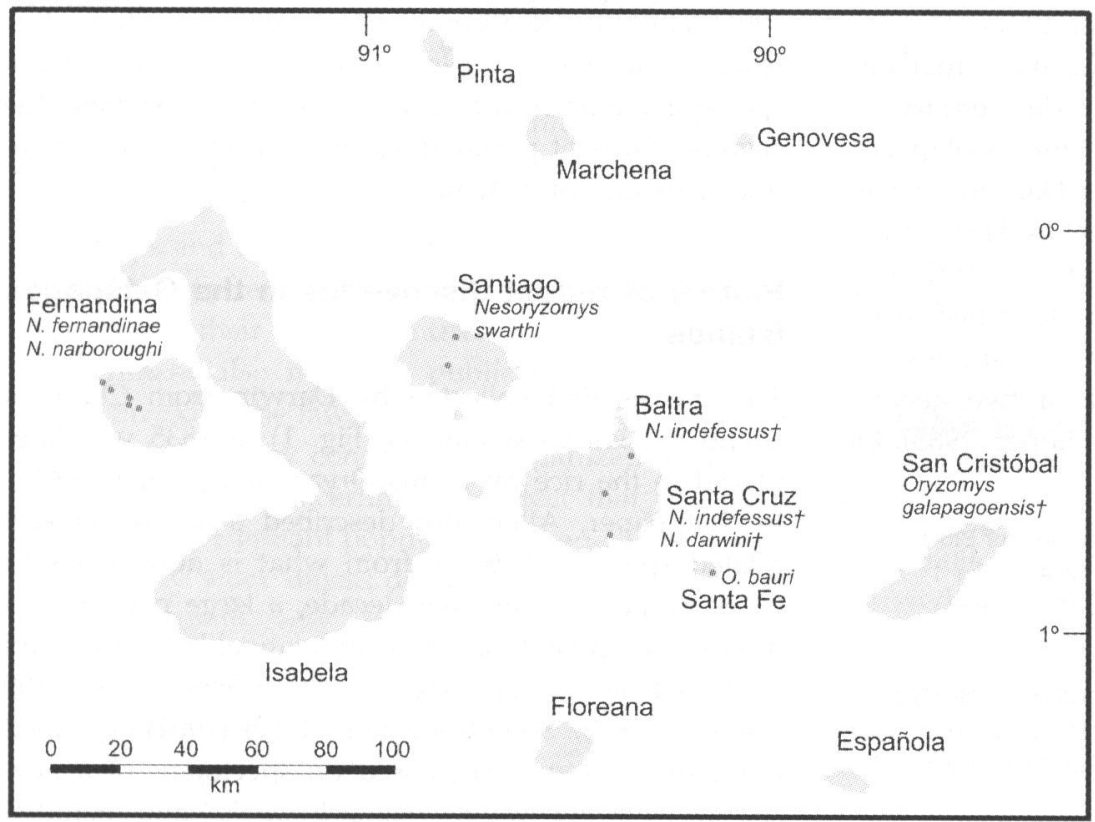

Fig. 1 Map showing the current status of native rodent species in the Galápagos Islands. Dots represent areas sampled during field studies during 1995 and 1997. Species names marked with + are considered extinct. 
suggested that the three species be treated as races of a single species, under the name $N$. indefessus. The synopsis of rodent taxonomy by Musser \& Carleton (1993) recognized five species for the Galápagos Islands: $O$. galapagoensis (which includes $O$. bauri), N. indefessus (which includes $N$. narboroughi), N. swarthi, N. darwini and $N$. fernandinae. Some recent publications continue to recognize all seven species (Clark, 1984; Steadman \& Zousmer, 1988; Steadman et al., 1991; Key \& Muñoz Heredia, 1994). For purposes of clarity, we will follow Corbet \& Hill (1986) and retain the original names for all seven taxa for discussion herein. A systematic assessment using mitochondrial DNA variation for all taxa except $O$. galapagoensis is currently in progress and should help resolve the taxonomic problems involving the native rodents of the Galápagos.

\section{Conservation status of rodents to 1995}

The status of the endemic and introduced rodents of the Galápagos Islands has been the topic of many papers over the past 40 years. Attention was drawn to the extinction of several native rodent species by Brosset (1963), although the suggestion that some species might be extinct dates back to the original description of $N$. swarthi (Orr, 1938). The most complete summary of the history of discovery and decline of the Galápagos rodents is found in Patton \& Hafner (1983) and Clark (1984). Most recently, Key \& Muñoz Heredia (1994) summarized recent distributions and added information relating to the addition of $R$. norvegicus to the introduced rodents on Santa Cruz.

In summary, up until the mid-1990s, four of the seven known species of endemic rodents have been considered extinct. Almost all publications on Galápagos rodents since 1963 report that $O$. galapagoensis on San Cristóbal, N. indefessus on both Santa Cruz and Baltra, N. darwini on Santa Cruz and N. swarthi on Santiago are extinct (Brosset, 1963; Niethammer, 1964; Orr, 1966; Patton \& Hafner, 1983; Clark, 1984; Steadman \& Zousmer, 1988; Steadman et al., 1991; Key \& Muñoz Heredia, 1994). Oryzomys galapagoensis has not been collected on San Cristóbal since 1835. Nesoryzomys darwini and $N$. indefessus from Santa Cruz have not been collected since 1930 and 1934, respectively (Patton \& Hafner, 1983; Clark, 1984). The extinction of these species on Santa Cruz is attributed to the introduction of black rats $R$. rattus during the late 1930s (Brosset, 1963; Clark, 1984).

Charles Darwin visited the island of Santiago in 1835 and collected $R$. rattus, which had probably been introduced to the island by early sailors or pirates. He did not collect any endemic rodent species at that time. In 1906, four specimens in the genus Nesoryzomys were collected on Santiago by J. S. Hunter of the California Academy of Science Expedition; however, these remained unreported until 1938 when they were described as a new species, $N$. swarthi, by Orr (1938). In his description, Orr stated that no specimens had been taken since the original collection in 1906 and that this species could be extinct at the time of the description. A single partial skull was found on Santiago in 1965 by a researcher at the Royal Ontario Museum, leading Peterson (1966) to speculate that a population of $N$. swarthi may still exist on that island. However, subsequent collecting in the 1970s (Patton \& Hafner, 1983; Clark, 1984) and later field studies by personnel of the Galápagos National Park revealed only $R$. rattus and M. musculus on Santiago. Most publications since the late $1960 \mathrm{~s}$ have considered N. swarthi to be extinct, most recently IUCN (1996) and Nowak (1999).

On Fernandina, N. fernandinae was described from fresh owl pellet remains (Hutterer \& Hirsch, 1980); however, no living specimens were collected into the 1990s. Most considered N. fernandinae to be extant (Clark, 1984; Steadman \& Zousmer, 1988; Key \& Muñoz Heredia, 1994), but IUCN (1996) listed it as extinct. Also included on that list were $N$. darwini and N. swarthi but, interestingly enough, $N$. indefessus was not. Presumably, this is because they used the taxonomy presented in Wilson \& Reeder (1993), which placed $N$. narboroughi, common on Fernandina, in synonomy with $N$. indefessus. Table 1 summarizes the status of populations of endemic rodents in the Galápagos Islands based on published accounts and on our field studies presented here.

\section{Materials and methods}

Our field surveys during 1995 and 1997 were conducted to assess rapidly the rodent faunas at 11 sites on four islands. We conducted surveys of the rodent fauna on the island of Fernandina from 1 to 14 August 1995 and on Santa Cruz, Santiago and Santa Fe islands from 19 July to 9 August 1997. A total of five sites was sampled on Fernandina, three on Santa Cruz, two on Santiago and one on Santa Fe (Fig. 1). Rodents were collected using Sherman live traps $(230 \times 77 \times 90 \mathrm{~mm})$ baited with a mixture of peanut butter and rolled oats. During part of the field studies some larger Sherman traps $(357 \times 100 \times 120 \mathrm{~mm})$ and Tomahawk cage traps $(406 \times 127 \times 127 \mathrm{~mm})$ were also used. Specimens collected were sexed, measured, weighed and released at the site of capture, with the exception of voucher specimens prepared as museum study skins or fluidpreserved specimens. These specimens are deposited at the Angelo State Natural History Collection of Angelo State University, with representatives to be deposited 


\begin{tabular}{lllll}
\hline Species & Distribution & First report & Last collection & Status \\
\hline Oryzomys bauri & Santa Fe & 1891 & 1997 & Extant \\
Oryzomys galapagoensis & San Cristóbal & 1835 & 1835 & Extinct \\
Nesoryzomys darwini & Santa Cruz & 1906 & 1930 & Extinct \\
Nesoryzomys fernandinae & Fernandina & 1980 & 1995 & Extant \\
Nesoryzomys indefessus & Baltra & 1898 & 1929 & Extinct \\
& Santa Cruz & 1897 & 1934 & Extinct \\
Nesoryzomys narboroughi & Fernandina & 1899 & 1997 & Extant \\
Nesoryzomys swarthi & Santiago & 1906 & 1997 & Extant \\
\hline
\end{tabular}

Table 1 Status of endemic rodent species of the Galápagos Islands

Data are summarized from Patton \& Hafner (1983), Clark (1984) and field studies reported herein.

eventually in the United States National Museum and at the Charles Darwin Research Station, Galápagos Islands, Ecuador.

The five sites surveyed on Fernandina included: one coastal site, $0^{\circ} 18^{\prime} 05^{\prime \prime} \mathrm{S}, 91^{\circ} 39^{\prime} 08^{\prime \prime} \mathrm{W}$; Cape Douglas, elevation about $5 \mathrm{~m}$, one low elevation inland site, $0^{\circ} 19^{\prime} 22^{\prime \prime} \mathrm{S}$, $91^{\circ} 38^{\prime} 19^{\prime \prime} \mathrm{W}$, elevation about $80 \mathrm{~m}$; and three sites around the volcano caldera rim, $0^{\circ} 21^{\prime} 38^{\prime \prime} \mathrm{S}, 91^{\circ} 33^{\prime} 55^{\prime \prime} \mathrm{W}$, elevation about $1360 \mathrm{~m}, 0^{\circ} 21^{\prime} 52^{\prime \prime} \mathrm{S}, 91^{\circ} 34^{\prime} 01^{\prime \prime} \mathrm{W}$, elevation about $1330 \mathrm{~m}$, and $0^{\circ} 23^{\prime} 26^{\prime \prime} \mathrm{S}, 91^{\circ} 34^{\prime} 01^{\prime \prime} \mathrm{W}$, elevation about $1330 \mathrm{~m}$. Sites sampled on Santa Cruz included the Charles Darwin Research Station at Puerto Ayora $\left(0^{\circ} 44^{\prime} 33^{\prime \prime} \mathrm{S}, 90^{\circ} 18^{\prime} 11^{\prime \prime} \mathrm{W}\right)$, a site in the north-central part of the island $\left(0^{\circ} 34^{\prime} 20^{\prime \prime} \mathrm{S}, 90^{\circ} 19^{\prime} 49^{\prime \prime} \mathrm{W}\right)$ and a coastal site just south of Punta Carrión ( $\left.0^{\circ} 29^{\prime} 50^{\prime \prime} \mathrm{S}, 90^{\circ} 14^{\prime} 57^{\prime \prime} \mathrm{W}\right)$. The two sites sampled on Santiago were La Bomba, a coastal site on the north-central coast $\left(0^{\circ} 11^{\prime} 10^{\prime \prime} S\right.$, $\left.90^{\circ} 41^{\prime} 59^{\prime \prime} \mathrm{W}\right)$, and El Central, a site in the highlands $\left(0^{\circ} 14^{\prime} 24^{\prime \prime} \mathrm{S}\right.$, $90^{\circ} 45^{\prime} 06^{\prime \prime} \mathrm{W}$, elevation about $\left.600 \mathrm{~m}\right)$. On Santa $\mathrm{Fe}$, we sampled rodents at the east end of the island $\left(0^{\circ} 48^{\prime} 22^{\prime \prime} \mathrm{S}, 90^{\circ} 02^{\prime} 34^{\prime \prime} \mathrm{W}\right)$.

\section{Results}

\section{Santa $\mathrm{Fe}$}

We found the Santa Fe rice rat Oryzomys bauri to be abundant at the collecting site on Santa Fe. In the single collecting effort on 9 August, in which 84 traps were set, we caught 69 individuals (82 per cent trap success). A sample of 57 examined individuals had a sex ratio 1.3:1 in favour of males. No females were obviously pregnant or lactating, but 11 of 27 males examined were scrotal. Rice rats could be seen running among the lava before dark and some captures were made during daylight hours. No evidence of introduced rats or mice was found at the site and Santa Fe appears to remain one of the few islands of the Galápagos without introduced species of rodents.

\section{Santa Cruz}

We selected two field sites that were previously unsampled and represented areas of Santa Cruz that were distant from inhabited areas to increase the likelihood of finding relict populations of endemic rodents. At both sites sampled, we collected only black rats $R$. rattus and house mice $M$. musculus. In addition to the two introduced rodent species, we found evidence of cats at both field sites. We also collected at the Charles Darwin Research Station in Puerto Ayora and caught both introduced species of rodents, as well as the Norway rat $R$. norvegicus, a third recently introduced species reported on that island (Key \& Muñoz Heredia, 1994). We found no evidence to suggest that the two species of endemic rodents, $N$. indefessus and $N$. darwini, still exist on Santa Cruz.

\section{Fernandina}

The results of field studies on Fernandina revealed two species of rodents - the large Fernandina rice rat $N$. narboroughi and the previously unreported small Fernandina rice rat $N$. fernandinae- at each of five sites sampled. The documentation of $N$. fernandinae allowed the first opportunity to describe the appearance of this species, previously known only from skeletal remains. Details of these results were reported by Dowler \& Carroll (1996). In summary, N. fernandinae can be distinguished from $N$. narboroughi by its smaller size-average mass, $32.3 \mathrm{~g}(n=27)$ compared with $77.5 \mathrm{~g}(n=86)$. External measurements for $N$. fernandinae are presented in Table 2. This species is also characterized by darker brown pelage and dark feet compared with the slightly lighter shade of greyish black pelage and white feet of N. narboroughi (Plate 1). Nesoryzomys narboroughi was common at the coastal site at Cape Douglas, with an overall trap success of 42 percent relative to a trap success of only 1 per cent for $N$. fernandinae. The highest 


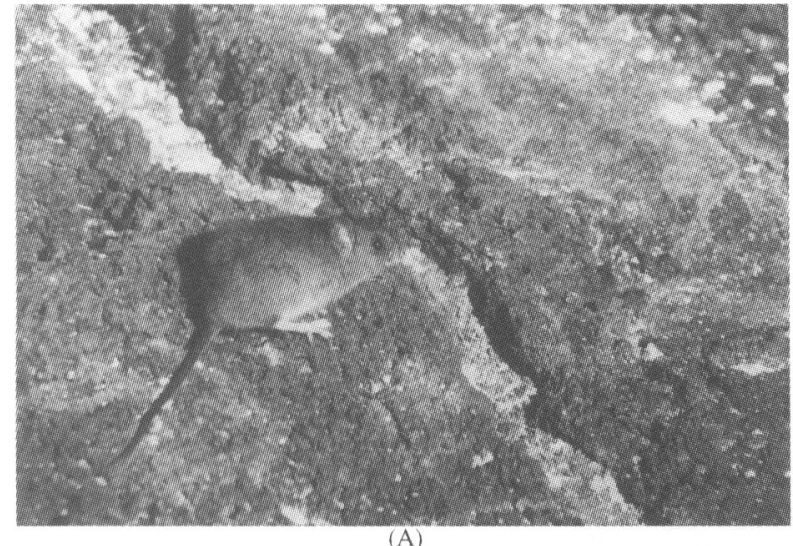

(A)
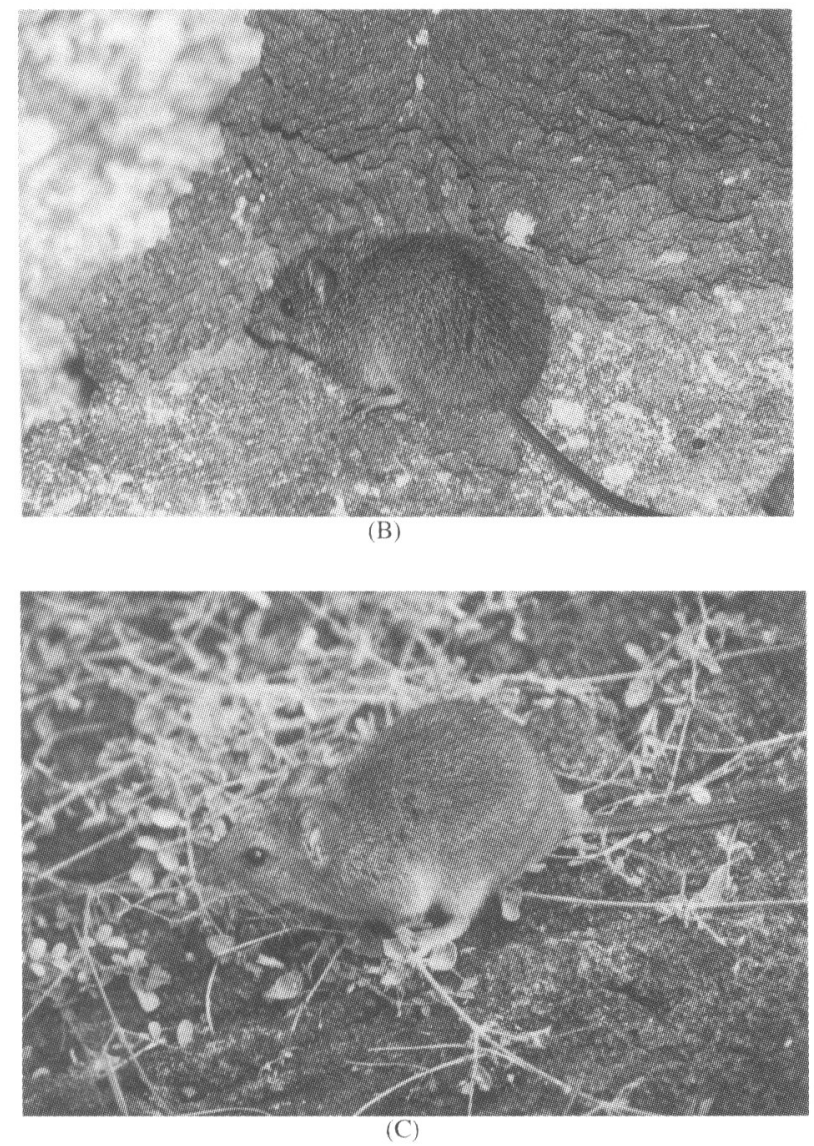

Plate 1 Photographs of the three extant species of Galápagos rice rats in the genus Nesoryzomys. (A) Nesoryzomys narboroughi from Fernandina. (B) Nesoryzomys fernandinae from Fernandina. (C) Nesoryzomys swarthi from Santiago. (Photographs: (A) and (B) Robert C. Dowler; (C) Cody W. Edwards.)

trap success for $N$. fernandinae was at high-elevation sites along the volcano rim where vegetation, primarily Scalasia spp., was most dense. At one such site, trap success was 27 per cent compared with 8 per cent for $N$. narboroughi. Six voucher specimens of $N$. fernandinae and 10 of N. narboroughi were collected.

\section{Santiago}

Our field work on Santiago was conducted between 31 July and 4 August 1997 at two sites. At a highland site, El Central, we collected only $R$. rattus and M. musculus. At a second locality, near the beach landing site called La Bomba, we collected $74 N$. swarthi (Plate 1), in 2 nights of trapping. In the same trap lines, we caught $R$. rattus and $M$. musculus, but in much smaller numbers (29 and 10, respectively). Trap success based on a total of 145 traps for 1 August was 17.9 per cent for $N$. swarthi, 11.7 per cent for $R$. rattus and 2.1 per cent for $M$. musculus. On 4 August, the same number of traps were concentrated in areas where $N$. swarthi had been taken on the 1 August survey. Trap success was 33 per cent for $N$. swarthi, 8 per cent for $R$. rattus and 4.8 per cent for $M$. musculus. The specimens of $N$. swarthi represent the first living endemic rodents taken on Santiago since 1906 and confirm the existence of a viable population on the island. Habitat at this location was arid thorn scrub with Palo Santo trees Bursera graveolens and Opuntia cactus (Plate 2). Table 2 lists the measurements and mass for a sample of specimens of N. swarthi. Sex ratio for a sample of 48 collected on 4 August was essentially even, with a $1.09: 1.00$ ratio of females to males. No females were lactating or obviously pregnant, but 8 of 22 adult males were scrotal. Five specimens were preserved as museum voucher specimens and are currently housed in the mammal collection of the Angelo State Natural History Collections, Angelo State University. These specimens double the number of museum specimens for this species.

\section{Discussion}

The verification of good populations of $O$. bauri on Santa Fe and of $N$. narboroughi on Fernandina was not unexpected. These species have been considered common on the two islands by virtually all researchers visiting the islands (Clark, 1980; Patton \& Hafner, 1983; Clark 1984; Key and Muñoz Heredia, 1994). The two species were considered by many to be the only extant rodents endemic to the Galápagos Islands and N. narboroughi was considered to be the only extant member of the genus Nesoryzomys prior to the discovery of skulls of N. fernandinae (Hutterer \& Hirsch, 1980). Santa Fe and Fernandina are the only two islands with native rodents that do not have introduced species of rats and mice.

The verification that $N$. fernandinae is an extant member of the Galápagos fauna is significant for two reasons. First, it dispels the current idea in the literature that this species is extinct (IUCN, 1996; Nowak, 1999). Second, Fernandina represents the second island, in 


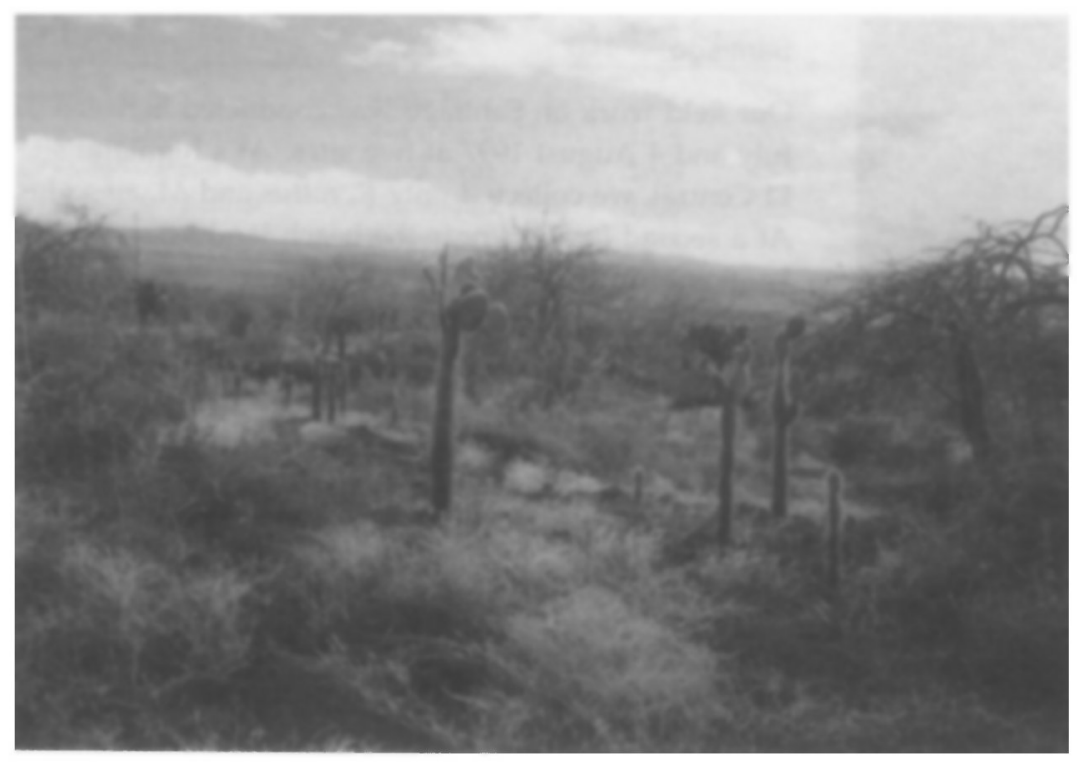

Plate 2 Habitat at the site where a population of the Santiago rice rat Nesoryzomys swarthi was discovered (Robert C. Dowler). addition to Santa Cruz, in the Galápagos on which both a large and a small form of rice rat occur, and now the only island where sympatric species of native rodents are extant. This will allow the possibility of future ecological studies regarding niche subdivision in Nesoryzomys.

The presence of $N$. fernandinae, in addition to $N$. narboroughi, at all localities sampled, including the coastal site, was surprising. The sympatry of the two species was suggested initially by the mix of skulls found in owl pellets by Hirsch (Hutterer \& Hirsch, 1980). The species distributions appear to be somewhat habitat-influenced, as indicated by the prevalence of $N$. narboroughi captures at the coastal site and the majority of $N$. fernandinae captures at the volcano rim (Dowler \& Carroll, 1996). Collections at areas along the eastern coast, including mangrove sites, should be conducted to determine if both species occur on the eastern side of the island or if the sympatry is restricted to western localities on Fernandina.

The discovery of a population of the Santiago rice rat $N$. swarthi is especially significant. This species, formerly known only by the type series of four specimens collected in 1906 (Orr, 1938) and a single partial skull found in 1965 (Peterson, 1966), has long been presumed extinct on Santiago. Despite periodic efforts during the

Table 2 Length measurements ( $\mathrm{mm}$ ) and total live mass $(\mathrm{g})$ of N. fernandinae and N. swarthi from the Galápagos Islands

\begin{tabular}{|c|c|c|c|c|c|c|}
\hline & & Total & Tail (mm) & Hind foot (mm) & Ear $(\mathrm{mm})$ & Mass $(\mathrm{g})$ \\
\hline \multirow[t]{8}{*}{ N. fernandinae } & Males $(n=14)$ & & & & & \\
\hline & Mean & $205.0^{*}$ & 90.1 & 25.3 & 17.3 & 38.1 \\
\hline & $\mathrm{SE}$ & 6.2 & 1.4 & 0.3 & 0.4 & 3.2 \\
\hline & Range & $184-221$ & $82-100$ & $23-27$ & $15-19$ & $25-63$ \\
\hline & Females $(n=13)$ & & & & & \\
\hline & Mean & $196.0^{*}$ & 84.1 & 23.5 & 15.8 & 26.9 \\
\hline & SE & 1.9 & 1.2 & 0.4 & 0.2 & 1.9 \\
\hline & Range & $194-198$ & $77-92$ & $21-26$ & $15-18$ & $22-47$ \\
\hline \multirow[t]{8}{*}{ N. swarthi } & Males $(n=22)$ & & & & & \\
\hline & Mean & 285.1 & 140.5 & 35.6 & 22.4 & 105.8 \\
\hline & $\mathrm{SE}$ & 42.7 & 15.2 & 2.4 & 1.4 & 37.1 \\
\hline & Range & $171-353$ & $100-163$ & $29-40$ & $20-25$ & 31-181 \\
\hline & Females $(n=25)$ & & & & & \\
\hline & Mean & 268.8 & 128.2 & 33.6 & 21.7 & 82.1 \\
\hline & $\mathrm{SE}$ & 33.5 & 14.3 & 1.3 & 1.2 & 33.5 \\
\hline & Range & $212-328$ & $107-157$ & $31-36$ & $19-24$ & $46-148$ \\
\hline
\end{tabular}

Total length of $N$. fernandinae $\left(^{*}\right)$ is based on samples of six males and two females. 
past four decades to survey the island for remnant populations of N. swarthi, this species has gone undetected. On that basis, IUCN (1996) listed N. swarthi as extinct. The discovery of this population gives some hope that more thorough field surveys for rodents on other islands may reveal extant populations of native species not currently thought to exist. Our research also documents the co-existence of an endemic species of Nesoryzomys with both $R$. rattus and $M$. musculus. This finding suggests that $R$. rattus, collected by Darwin in 1835 , and $N$. swarthi, later discovered on the island, have co-existed on Santiago for over 160 years. This is evidence that at least some native rodents in the Galápagos Islands can successfully compete with $R$. rattus. The discovery of living populations of both $N$. fernandinae and $N$. swarthi also now allows further analysis of systematic relationships, based on proteins, DNA and chromosomes, within the genus Nesoryzomys.

Although the evidence is circumstantial, the most likely cause of extinction in $O$. galapagoensis, $N$. indefessus and $N$. darwini is the introduction of black rats to the islands where they occurred. Either through the introduction of pathogens to which native species were susceptible or through direct competition, black rats certainly have played a role in the rapid decline and presumed extinction of Nesoryzomys on Santa Cruz (Brosset, 1963; Niethammer, 1964; Clark, 1984; Key \& Muñoz Heredia, 1994). This presumption is based on historical observations of the first black rats on Santa Cruz, which was followed by rapid expansion of the introduced species and concomitant decline of the native rodents (Clark, 1984). With the rediscovery of $N$. swarthi co-existing with both black rats and house mice on Santiago, there is now evidence that introduced rodents may not be the sole cause of decline in native rodents in the Galápagos. Feral house cats in the archipelago may be a second important factor in rodent decline and extinction. On all islands where native rodents are now considered extinct-Santa Cruz, Baltra and San Cristóbal-feral cats have been introduced. Whether cat introductions paralleled the timing of black rat introductions is not known, but the impact of feral cats on native populations of other vertebrates is well documented (e.g. Ebenhard, 1988).

\section{Recommendations for conservation of the endemic rodents}

There is little doubt that the populations of the endemic species of rodents on Fernandina, Santiago and Santa $\mathrm{Fe}$ are vulnerable to extinction. The history of the decline and likely extinction of the other species within the genus Nesoryzomys on Santa Cruz, with the increase and spread of introduced rodents, has been well documented (Brosset, 1963; Niethammer, 1964; Patton et al., 1975; Clark, 1984; Key and Muñoz Heredia, 1994). To date, however, no conservation efforts have been directed at the native terrestrial rodents of the Galápagos Islands. Three primary strategies for conservation of the endemic rodents should be initiated: 1) a monitoring system should be established for early detection of introduced mammals to Fernandina and Santa $\mathrm{Fe}$; 2) an emergency plan should be developed for eradication of introduced species to Fernandina and Santa $\mathrm{Fe}$, in the event that an introduction occurs; and 3) an effort should be made to establish $e x$ situ colonies of the endemic rodent species as a safeguard to extinction. Finally, continued surveys should be undertaken on islands that may still have unknown relict populations of native rodents.

The establishment of a regular monitoring programme to detect the introduction of non-native rats and mice, and cats, dogs or other predators to the islands of Fernandina and Santa Fe is essential to the long-term preservation of the indigenous rodents of the Galápagos Islands. Annual, or more frequent, surveys should be conducted at areas where the greatest likelihood of introductions exists. These areas should include primarily coastal sites where fishing boats might make illegal landings and camps. Although tourist visitor sites might also be targeted, the probability of rodent or cat introductions at these areas is minimal.

In conjunction with the monitoring programme, an emergency action plan should be approved by the Galápagos National Park for implementation in the event that introduced mammals are discovered on Fernandina or Santa Fe. The importance of early action to control any introduced population of either rodents or cats cannot be overemphasized. The conflict between controlling an introduced rodent species while maintaining populations of the native ones is a difficult situation. Early detection of the introduction might allow action on a small population of introduced rats, at the expense of killing a small subpopulation of the native species, e.g. through an intense poisoning campaign. The net benefit would be far better than the risk of island-wide populations of black rats or Norway rats. For the most part, the same would hold true for the introduction of cats. Early detection would allow a far greater chance of successful eradication of the predator, with limited impact on the native rodent species.

In 1986, Trillmich suggested that the vulnerability of the native Galápagos rodents to extinction warranted the establishment of captive breeding colonies. Unfortunately, virtually nothing is known about the biology of 
most of the native rodent species in the Galápagos Islands. At the ecological level, only $O$. bauri has been studied in detail (Clark, 1980). There are consequently few, if any, available data for the effective ex situ management of any of the indigenous species of rodents. For this reason, if captive management plans were initiated at the time of a crisis, such as might exist if introduced species were discovered on Fernandina or Santa Fe, the chance of success might well be hampered. We agree with Trillmich (1986) and suggest that captive management of the native rodent species be initiated immediately as a potential protection from extinction. Information on diet requirements, breeding protocols, susceptibility to either disease or parasites, and level of genetic variability will all prove to be instrumental in any conservation effort that involves maintaining colonies in captivity for possible reintroduction, in the case of extirpation of wild populations. Preferably, such captive management should be conducted by zoo professionals, who might have the funds, facilities and expertise to establish such colonies. This recommendation for ex situ conservation is also in line with priorities proposed for zoos by Balmford et al. (1996). These authors recommended that ex situ conservation efforts at zoos target small-bodied taxa with a high probability of successful reproduction and for which habitat for reintroduction exists. The native rodents of the Galápagos Islands are ideal candidates for such conservation efforts, based on these criteria.

In addition to the above suggestions, a thorough survey should be conducted of the islands where relict populations of native rodents may occur. This approach was responsible for the discovery of two species whose existence was in doubt. There remains a remote possibility that $O$. galapagoensis may still occur on San Cristóbal, in western areas of the island where few surveys of rodents have been conducted. These areas include the site at which Darwin collected the only known specimens of this species and, to our knowledge, they have never been resurveyed. On Santa Cruz and Baltra, there remains little hope that populations of $N$. indefessus or $N$. darwini still exist. However, the recent discovery of a cave with skeletal material from both Nesoryzomys and Megaoryzomys curioi, with that of the house mouse $M$. musculus, suggests the possibility that even a Galápagos giant rat existed on Santa Cruz in the very recent past (Hutterer \& Oromí, 1993). Unfortunately, surveys on several parts of the island during the past decade have revealed only introduced rats and mice, including populations of Norway rats.

Perhaps the best chance of finding existing populations of currently unknown native rodents lies on Isabela, the largest island in the Galápagos. Fossil remains of both large and small species of Nesoryzomys, as well as remains of an undescribed giant Galápagos rat, genus Megaoryzomys, have been found there (Steadman, 1981; Steadman \& Ray, 1982; Steadman \& Zousmer, 1988). More interesting is the fact that, although no specimens of native rodent species have ever been collected from Isabela, Steadman et al. (1991) reported that skeletal material from rodents on that island, dated using radiocarbon methods, has ages that overlap with historical human settlement of the island, and potentially into this century. Further field surveys are warranted, despite the presence of both black rats and house cats on the island. Surveys of Isabela and the other islands that may still have extant native rodent populations, as well as further surveys to delimit the present distribution of the endemic species on Santiago and Fernandina, are currently under way.

\section{Acknowledgements}

We wish to thank the Galápagos National Park and especially Eliecer Cruz for issuing the permits that allowed this research to be conducted. We gratefully acknowledge Robert Bensted-Smith and Chantal Blanton, and the staff of the Charles Darwin Research Station for assistance in planning and carrying out this project. Further logistic support was provided by Howard Snell, Heidi Snell, David Parer, David Day, Marta Romo Leroux, Laura Chellis, Bernardo Gutierre and Lenin Cruz. Finally, we thank our field assistants, Diana Vinueza, Tanya Nolivos, Osvaldo Sanchez and Simon Villamar, without whose help we would have been unable to complete this study. Albert Freeman and Jack Wilcox assisted with figures. Funding for this project was provided by Research Enhancement Grants through Angelo State University. Tame Airlines of Ecuador provided transportation to and from the Galápagos at reduced rates.

\section{References}

Allen, J.A. (1892) On a small collection of mammals from the Galápagos Islands, collected by Dr G. Baur. Bulletin of the American Museum of Natural History, 4, 47-50.

Balmford, A., Mace, G.M. \& Leader-Williams, N. (1996) Designing the ark: setting priorities for captive breeding. Conservation Biology, 10, 719-727.

de Beaufort, F. (1963) Les cricétinés de Galápagos. Valeur du genre Nesoryzomys. Mammalia, 27, 338-340.

Brosset, A. (1963) Statut actuel des mammiferes des Iles Galápagos. Mammalia, 27, 323-338.

Cabrera, A. (1961) Catalogo de los mamiferos de America del Sur. Revista del Museo Argentino de Ciencieas Naturales 'Bernardino Rivadavia'. Ciencias Zoologicas, 4 , 309-732. 
Clark, D.A. (1984) Native land mammals. In Key Environments: Galápagos (ed. R. Perry), pp. 225-231. Pergamon, Oxford.

Clark, D.B. (1980) Population ecology of an endemic Neotropical island rodent: Oryzomys bauri of Santa $\mathrm{Fe}$ Island, Galápagos, Ecuador. Journal of Animal Ecology, 49, $185-198$.

Corbet, G.B. \& Hill, J.E. (1980) A World List of Mammalian Species. British Museum (Natural History), London.

Corbet, G.B. \& Hill, J.E. (1986) A World List of Mammalian Species, 2nd edn. British Museum (Natural History), London.

Dowler, R.C. \& Carroll, D.S. (1996) The endemic rodents of Isla Fernandina: population status and conservation issues. Noticias de Galápagos, 57, 8-13.

Ebenhard, T. (1988) Introduced birds and mammals and their ecological effect. Swedish Wildlife Research, 13, 1-107.

Ellerman, J.R. (1941) The Families and Genera of Living Rodents, vol. 2. British Museum (Natural History), London.

Gardner, A.L. \& Patton, J.L. (1976) Karyotypic variation in oryzomyine rodents (Cricetinae) with comments on chromosomal evolution in the Neotropical cricetine complex. Occasional Papers of the Museum of Zoology, Louisiana State University, 49, 1-48.

Heller, E. (1904) Mammals of the Galápagos archipelago, exclusive of the Cetacea. Proceedings of the California Academy of Sciences, 3, 233-251.

Hutterer, R. \& Hirsch, U. (1980) Ein neuer Nesoryzomys von der Insel Fernandina, Galápagos. Bonner Zoologische Beiträge, 30, 276-283.

Hutterer, R. \& Oromí, P. (1993) La rata gigante de la Isla Santa Cruz, Galápagos: algunos datos y problemas. Resultados Cientificos del Proyecto Galápagos, Patrimonio de la Humanidad, Museo de Ciencias Naturales, Tenerife (TFMC), 4, 63-76.

IUCN (1996) 1996 ILCN Red List of Threatened Animals. IUCN, Gland, Switzerland.

Key, G. \& Munoz Heredia, E. (1994) Distribution and current status of rodents in the Galápagos. Noticias de Galápagos, 53, 21-25.

Musser, G.G. \& Carleton, M.D. (1993) Family Muridae. In Mammal Species of the World. A Taxonomic and Geographic Reference (eds D. E. Wilson and D. M. Reeder), pp. 501-755. Smithsonian Institution Press, Washington, DC.

Niethammer, J. (1964) Contribution á la connaissance des mammiféres terrestres de L'ile Indefatigable (á Santa Cruz), Galápagos. Résultats de l'expédition allemande aux Galápagos 1962/63, No. VIII. Mammalia, 28, 593-606.

Nowak, R.M. (1999) Walker's Mammals of the World, 6th edn. The Johns Hopkins University Press, London.

Orr, R.T. (1938) A new rodent of the genus Nesoryzomys from the Galápagos Islands. Proceedings of the California Academy of Sciences, Ser. 4, 23, 303-306.

Orr, R.T. (1966) Evolutionary aspects of the mammalian fauna of the Galápagos. In The Galápagos (ed. R. I. Bowman), pp. 276-281. University of California, Berkeley, CA.

Osgood, W.H. (1929) A new rodent from the Galápagos Islands. Field Museum of Natural History, Zoological Series, 17, 21-24.
Patton, J.L. \& Hafner, M.S. (1983) Biosystematics of the native rodents of the Galápagos archipelago, Ecuador. In Patterns of Evolution in Galápagos Organisms (eds R. I. Bowman, M. Berson and A. E. Leviton), pp. 539-568. AAAS Pacific Division, San Francisco, CA.

Patton, J.L., Yang, S.Y. \& Myers, P. (1975) Genetic and morphologic divergence among introduced rat populations (Rattus rattus) of the Galápagos archipelago, Ecuador. Systematic Zoology, 24, 296-310.

Peterson, R.L. (1966) Recent mammal records from the Galápagos Islands. Mammalia, 30, 441-445.

Steadman, D.W. (1981) Vertebrate fossils in lava tubes in the Galápagos Islands, abstract. Proceedings of the 8 th International Congress of Speleology, Vols. I and II, pp. $549-550$.

Steadman, D.W. \& Ray, C.E. (1982) The relationships of Megaoryzomys curioi, an extinct cricetine rodent (Muroidea: Muridae) from the Galápagos Islands, Ecuador. Smithsonian Contributions to Paleontology, 51, $1-23$.

Steadman, D.W., Stafford, T.W. Jr., Donahue, D.J. \& Jull., A.J.T. (1991) Chronology of Holocene vertebrate extinction in the Galápagos Islands. Quaternary Research, 36, 126-133.

Steadman, D.W. \& Zousmer, S. (1988) Galápagos: Discovery on Darwin's Islands. Smithsonian Institution Press, Washington, DC.

Thomas, O. (1899) Descriptions of new Neotropical mammals. Annals and Magazine of Natural History, Ser. 7, 4, 278-288.

Trillmich, F. (1986) The future of the Fernandina rice rats: extinction or captive breeding? Noticias de Galápagos, 44, $15-16$.

Waterhouse, G.R. (1839) The Zoology of the Voyage of HMS Beagle, under the Command of Captain Fitzroy, R. N., During the Years 1832 to 1836. Part 2. Mammalia. Smith, Elder and Co., London.

Wilson, D.E. \& Reeder, D.M. (1993) Mammal Species of the World. A Taxonomic and Geographic Reference. Smithsonian Institution Press, Washington, DC.

\section{Biographical sketches}

Robert C. Dowler is the Mr and Mrs Victor P. Tippett University Professor of Biology at Angelo State University and Curator of Mammals at the Angelo State Natural History Collections. He is continuing to survey islands in the Galápagos archipelago for relict populations of native rodents and is analysing the systematic relationships of the Galápagos rice rats. He has also worked on the systematics of pocket gophers (Family Geomyidae) and has collaborated on a long-term project on the mammals of the Yucatan Peninsula of Central America with M. D. Engstrom of the Royal Ontario Museum.

Darin S. Carroll and Cody W. Edwards are currently completing the Ph.D. degree in Biological Sciences at Texas Tech University. Both are involved with molecular systematics of New World rodents. 